\title{
Impact of COVID-19 pandemic on anxiety, depression and distress - online survey results amid the pandemic in Russia
}

\author{
Влияние пандемии COVID-19 на уровень тревоги, депрессии и дистресса: \\ результаты онлайн-опроса в условиях пандемии в России \\ DOI: 10.17650/2712-7672-2020-1-1-8-20
}

\author{
Olga A. Karpenko, Timur S. Syunyakov, Maya A. \\ Kulygina, Alexey V. Pavlichenko, Anastasia S. \\ Chetkina, Alisa V. Andrushchenko \\ Mental-health clinic No. 1 named after N.A. Alexeev, Moscow, \\ Russia
}

\author{
Ольга А. Карпенко, Тимур С. Сюняков, Майя А. \\ Кулыгина, Алексей В. Павличенко, Анастасия С. \\ Четкина, Алиса В. Андрющенко \\ Психиатрическая клиническая больница № 1 \\ им. Н.А. Алексеева, Москва, Россия
}

\begin{abstract}
Background. In 2020, the COVID-19 pandemic evoked a variety of research into the virus and its effects on mental health. A variety of mental health and psychological problems have been reported: stress, anxiety, depressive symptoms, insomnia, denial, stigma, anger and fear.
\end{abstract}

Objectives. To assess the level of anxiety, depression and distress in the general population during the lockdown in Russia and to reveal factors associated with distress.

Methods. An online survey was carried out from 22-27 April 2020 (the fourth week of lockdown) among the general population (mostly Moscow residents). The survey questions covered general information about people's social and demographic characteristics, experience of COVID-19, health condition (physical and mental), attitudes and views on the pandemic, and the need for psychological support. The survey included the Hospital Anxiety and Depression Scale (HADS) and evaluation of the preceding week's subjective distress level using a visual numeric scale (from 0 to 10). We also asked respondents to specify the causes of distress, adopted from the WHO information sheet relating to the major psychological challenges of the COVID-19 pandemic.

Results. In total, 352 responses were collected (men $=74$, women $=278$; age $(M \pm S D)=36.81 \pm 11.36$ y.o.). Most respondents $(n=225,63.92 \%)$ did not have any personal experience of the coronavirus infection. Normal levels of anxiety and depression scores were prevalent in the sample. Higher than normal levels of HADS anxiety/ depression (> 7 scores) were observed in 105 (29.83\%) and 59 (16.76\%) respondents, respectively; mean (95\% Cl) scores for HADS anxiety/depression were $6.23[5.77,6.68] / 4.65[4.22,5.08]$ (women) and 4.20 [3.32, 5.09] /3.46 $[2.63,4.29]$ (men), respectively.

The leading causes of distress were: 1$)$ the risk of financial problems in the future $(n=267,76.3 \%) ; 2)$ violation of plans and the disruption to normal life ( $n=235,67.1 \%$; and $n=240,68.6 \%$, respectively); 3 ) the health of elderly or chronically diseased relatives $(n=205,58.6 \%)$ and 4 ) being in self-isolation $(n=186,53.1 \%)$. 
Conclusion. The level of anxiety and depression during the COVID-19 pandemic in the study sample did not exceed the norm for the population in non-pandemic conditions. Our assessment of distress levels captured existing emotional problems, and distress levels were found to be connected with the reported need for psychological support.

\section{АННОТАЦИЯ}

Введение. В 2020 году пандемия COVID-19 спровоцировала разнообразные исследования, в фокусе которых оказался и сам вирус, и влияние пандемии на психическое здоровье. В результате были выявлены разнообразные психиатрические нарушения и психологические реакции: стресс, тревога, депрессия, бессонница, отрицание, стигматизация, гнев и страх.

Цели. Измерить уровень тревоги, депрессии и дистресса у населения в период самоизоляции в России, выявить факторы, связанные с дистрессом.

Материал и методы. С 22 по 27 апреля 2020 года (четвертая неделя периода изоляции) был проведен онлайнопрос населения (в основном жителей Москвы). В ходе опроса собирались социальные и демографические данные о респондентах, опыте с COVID-19, состоянии здоровья (физического и психического), отношении к пандемии и мнению о ней, потребности в психологической поддержке. Опрос включал госпитальную шкалу тревоги и депрессии (HADS), а также оценку уровня субъективного дистресса за предыдущую неделю с использованием визуальной числовой шкалы (от 0 до 10). Кроме того, респондентов просили указать причины дистресса из списка, составленного на основе информационного листка ВОЗ о главных психологических проблемах, вызванных пандемией COVID-19.

Результаты. В общей сложности было собрано 352 ответа (от мужчин - 74, от женщин - 278; возраст (среднее \pm SD) - $36.81 \pm 11.36$ года). Большинство респондентов ( $n=225,63.92 \%)$ не имели какого-либо личного опыта, связанного с коронавирусной инфекцией. В группе преобладали нормальные уровни тревоги и депрессии. Уровень тревоги/депрессии по шкале HADS выше нормального (> 7 баллов) был отмечен у 105 (29.83\%) и 59 (16.76\%) респондентов соответственно; средний (95\% дИ) уровень тревоги/депрессии по шкале HADS составил 6,23 [5.77, 6.68] / 4,65 [4.22, 5.08] (женщины) и 4.20 [3.32, 5.09] / 3.46 [2.63, 4.29] (мужчины) соответственно.

Основными причинами дистресса были: 1) риск финансовых проблем в будущем ( $(n=267,76.3 \%) ; 2)$ нарушение планов и привычной жизни ( $(=235,67.1 \%$ и $n=240,68.6 \%$ соответственно); 3) здоровье пожилых или хронически больных родственников ( $(=205,58.6 \%) ; 4)$ нахождение в самоизоляции $(n=186,53.1 \%)$.

Выводы. В популяции участников исследования уровень тревоги и депрессии во время пандемии COVID-19 не превысил нормальные значения, характерные для населения в условиях без пандемии. Проведенный анализ уровня дистресса выявил существующие эмоциональные проблемы, была обнаружена связь между уровнем дистресса и потребностью, по мнению участника, в психологической поддержке.

Keywords: COVID-19, SARS-CoV-2, pandemic, distress, anxiety, depression, HADS, mental health, survey, Russia Ключевые слова: COVID-19, SARS-CoV-2, пандемия, дистресс, тревога, депрессия, HADS, психическое здоровье, опрос, Россия

\section{INTRODUCTION}

Since the beginning of 2020, the world has faced a major threat due to the global transmission of the new coronavirus disease COVID-19, a situation that was officially declared to be a pandemic by the World Health
Organization on 11 March. Unprecedented governmentlevel measures have been deployed on a massive scale, including the introduction of quarantine restrictions and prohibitions that minimize direct social contact and the spread of infection. Many countries have started studying 
COVID-19 and the impact of lockdown measures on the mental health and psychological well-being of the general population and various vulnerable groups.

Key factors associated with the COVID-19 pandemic have been identified: social isolation and distancing, quarantine, unemployment, caregiving, facing death or experiencing illness [1, 2]. Systematic reviews have reported expected psychological and mental health problems due to the outbreak of COVID-19, such as stress, anxiety, depressive symptoms, insomnia, denial, stigma, anger and fear [3]. According to findings in different countries around the globe, the COVID-19 pandemic increases negative emotionality, fear of infection or death, frustration, anger and feelings of guilt, loneliness and despair [4]. A nationwide survey of more than 50,000 Chinese people, carried out during the COVID-19 epidemic, showed that almost $35 \%$ of respondents had experienced psychological distress. This was associated with gender, age, education level, occupation and region. Males and young people demonstrated lower rates, while highly educated individuals and migrant workers experienced the highest level of distress. Availability of local medical resources, efficiency of the regional public health system and prevention and control measures taken in response to the epidemic also influenced the level of distress [5].

A high level of anxiety was detected at the initial stage of the COVID-19 epidemic in China [6, 7], Hong Kong [8] and Saudi Arabia [9]. More than half of the respondents rated the psychological impact as moderate, and about a third reported moderate anxiety [6]. A follow-up study conducted four weeks after the initial survey did not show a significant reduction in levels of distress, anxiety and depression [7]. Almost all respondents were alert to the progression of the coronavirus disease (99.5\%) [8].

A German study has revealed the association between behavioural and emotional responses to stress factors and gender and age. When asked to rate the risk of developing COVID-19, older people reported a lower figure than younger people, and women were more concerned about COVID-19 than men [10]. Psychological distress levels have been found to positively correlate with the female gender and pre-existing somatic symptoms; lower stress levels are associated with hygiene and precautionary measures, and trust in clinicians [7]. WHO data revealed a threefold increase in the prevalence of symptoms of depression in Ethiopia in April 2020, compared to figures obtained before the outbreak [11].
High levels of anxiety and depression have been identified in patients with COVID-19 [12]. In addition to these people, particular attention should be paid to at-risk groups: elderly people and people with chronic diseases, children and adolescents, caregivers, unemployed persons, socially disadvantaged people and individuals with mental disorders [4]. Some social groups (people on a low income, retired or divorced people and students) have been found to be at a higher risk of depression, while unemployment is associated with the risk of anxiety [9]. The parents of children hospitalized due to the pandemic have also been found to show increased levels of anxiety and depression [13].

Medical personnel who are on the front line in the fight against coronavirus, providing direct assistance to patients, are also of great concern. One study [14] focused on 1257 healthcare professionals working in hospitals or wards for Covid-19 patients in China. Assessment of their mental health showed high rates of depression (50.4\%), anxiety (44.6\%), insomnia (34.0\%) and distress (71.5\%), particularly among nurses, women, frontline healthcare workers and those working in the epidemic "hot zone" [15].

The results of a study investigating the psychological impact of COVID-19 among medical college students in China $(n=7143)$ indicated that $0.9 \%$ of respondents were experiencing severe anxiety; $2.7 \%$ moderate anxiety and $21.3 \%$ mild anxiety. Moreover, having personal experience of COVID-19 was a risk factor for increased anxiety, while living in urban areas, a stable family income and living with parents were found to be protective factors. Economic effects and the effects on daily life are directly associated with anxiety symptoms [16].

According to another study prognosis, levels of anxiety increase even further in due course, both through direct causes (including fear of contamination, stress, grief and depression triggered by exposure to the virus) and the influence of social and economic consequences on an individual and societal level [17].

Our study aimed to assess the level of anxiety, depression and distress among the general population during lockdown in Russia and to reveal the main causes of distress. This information could be helpful in developing strategies aimed at maintaining the psychological wellbeing of people and prevention of mental health problems. 
The study hypothesis was that amid the COVID-19 pandemic, and during a month of lockdown, people will have abnormal levels of anxiety and depression, while people's levels of distress will increase due to concerns about their own health and the health of loved ones, the threat to life from the pandemic and everyday difficulties due to lockdown.

\section{MATERIALS AND METHODS}

The survey context

In Russia, the pandemic situation began to gradually deteriorate in March 2020. Ever since the first case on 2 March, the capital city, Moscow, has been the centre of the epidemic in this country. At the same time, it also has the most modern, comprehensive and well-organized healthcare service in the country. On 25 March, the president declared a holiday from 30 March to 12 April, with salaries continuing to be paid. Employers were obliged to shift work to a remote regimen so that staff could carry on working if remote work was possible and get paid, regardless of their work involvement. The initial "holiday" period was prolonged until the end of April. All public events were cancelled. Shops were closed, except for food shops, pet shops and pharmacies, and all education processes shifted to a remote format. A pass control measure was introduced in Moscow and certain other regions. At the end of March, the transport cards of people over 65 years old who needed to stay at home for their own safety were suspended, as were those of school children and students. An even stricter regimen was introduced in Moscow on 15 April, according to which people were only allowed to leave their home to go to the nearest shop. Travelling longer distances was limited to twice a week, with a special pass. Violation of the restrictions resulted in penalties of 4000 roubles (US\$57) for each case. When we commenced our survey, the number of infected cases in Russia was about 58,000 (about 32,000 by 22 April in Moscow alone), and the numbers rose steadily by 5000-6000 every day, though the number of deaths was relatively low, with about 513 in total (261 in Moscow) and daily growth of about 50 cases [18]. Information about current events and the latest news relating to the pandemic were presented continuously on all TV channels and other media. A general sense of uncertainty arose due to the stepwise decisions of authorities regarding the lockdown regimen and very approximate deadlines set.

\section{Methods}

The survey, developed by the authors of this study, was performed online among the general population (mostly Moscow residents) from 22-27 April 2020 (the fourth week of lockdown). The researchers distributed links to the survey via social networks. People were asked to answer questions about their personal wellbeing during the COVID-19 pandemic by filling in the survey in Google forms, and the results were collected once respondents pushed the "submit" button. It was made clear that answering all the questions and pushing the "submit" button would be taken as a sign of voluntary consent to share answers. The survey was completely anonymous; no identifiable personal data or IP addresses were collected. Ethical approval was not obligatory due to the non-interventional online survey research design.

There were no special inclusion criteria for participants, except a minimum age requirement of 18 .

The survey questions covered general information about people's social and demographic characteristics, with an emphasis on occupation, living conditions, experience of COVID-19, health condition (physical and mental), attitudes and views on the pandemic and the need for psychological support. Respondents were then asked to fill in the Hospital Anxiety and Depression Scale (HADS) [19]. The HADS results were interpreted using recommended cut-offs for the scale (normal level: a score of 0-7; borderline abnormal: a score of 8-10; abnormal: a score of $>10$ ). Participants were asked to evaluate what their level of subjective distress had been during the preceding week using a visual numeric scale and to assess their level of distress using the 10-point scale (from 0 to 10 , where 0 is no distress, and 10 is maximal distress). Participants were also asked to specify the cause of distress by answering yes/no to a list of distress causes. Causes of distress were adopted from the WHO information sheet about the major psychological challenges of the COVID-19 pandemic [20], including the following: fear of getting infected; concerns about the health of loved ones; problems in interaction with children and a partner; distress due to the lockdown; a total change of plans and lifestyle; stigmatization due to COVID-19 and financial problems. The full version of the survey is shown in Appendix $A$ in the supplementary materials. 


\section{Statistical analysis}

\section{A. Primary endpoint}

The primary endpoint of the study was an evaluation of the frequency distribution of normal, borderline abnormal and abnormal levels of anxiety and depression HADS scores and mean HADS anxiety/ depression scores (HADS-A and HADS-D).

\section{$B$. Secondary endpoints of the study were evaluation of the following:}

1. demographic characteristics and factors connected with personal experience of COVID-19 and attitude towards COVID-19 information, and their association with levels of HADS-A and HADS-D;

2. the level of subjective distress;

3. major sources of distress among the general population during the fourth week of lockdown.

Categorical variables are presented as frequencies (\% and $95 \% \mathrm{Cl}$ limits for relative frequencies). To determine demographic factors associated with anxiety/depression levels, contingency tables were generated and then tested with the chi-square test. Continuous data are presented as means and 95\% margins of confidence intervals. Between-group comparisons of continuous variables were performed using ANOVA. The importance of demographic predictors, attitude towards COVID-19 information and sources of distress were estimated using general classification and regression tree models, where the distress score was the dependent variable. Variables with an importance of more than 0.25 were then selected for the final model, and after the cross-validation process, the regression tree model was generated. All tests were performed at a two-tailed significance level of $p<0.05$.

Statistical analysis was performed using XLSTAT 2019.3.2 (Addinsoft (2020), XLSTAT statistical and data analysis solution, New York, USA; htvtps:// www.xlstat.com.).

\section{RESULTS}

\section{Demography}

In total, 352 responses were collected $($ men $=74$, women = 278; age $(M \pm S D)=36.81 \pm 11.36$ y.o.). Most respondents ( $n=282,80.11 \%$ ) had a high level of education, and about a quarter ( $n=73,20.74 \%$ ) of those with a high level of education were medical doctors. Overall, 246 (69.89\%) people were working; 49 (13.92\%) were studying and the other 57 (16.19\%) were not working due to various reasons, including being retired, on maternity leave or for other reasons. At the time of the survey during lockdown, 133 (37.78\%) respondents had begun working remotely; 70 (19.89\%) were not working; 26 (7.39\%) had stopped working and were not getting paid; 17 (4.83\%) had stopped working but were being paid; 24 (6.82\%) were continuing to work from home as they had before the pandemic; 65 (18.47\%) were continuing to go to their usual workplace; $2(0.57 \%)$ had been fired during the pandemic and 4 (1.14\%) and 11 (3.12\%) were business owners whose businesses had continued to operate or had stopped operating respectively.

Most respondents lived in Moscow or its suburbs (n $=288,81.82 \%$ ), in an apartment 300 (85.23\%), and were satisfied with their living space $(n=251,71.31 \%)$. Only around half ( $n=196,55.68 \%$ ) had a partner; others were single; 52 (14.77\%) lived only with their partner; 49 (13.92\%) lived alone; 31 (8.81\%) had several generations under one roof (children and elderly relatives) and others lived with either children or elderly relatives. Full details of the demographic characteristics are given in Appendix $B$ in the supplementary materials.

Personal experience of COVID-19 and attitude towards COVID-19 information

In their responses to general questions about the pandemic situation, 197 (55.9\%) people said that they considered the COVID-19 pandemic to be really serious and a great danger to health; $53(15.1 \%)$ thought that it was not true and 102 (28.9\%) chose the "difficult to answer" option; 288 (81.6\%) were prepared to wait out the quarantine and had made all the recommended preparations; 321 (91.1\%) worried about their health and the health of their loved ones; 167 (47.6\%) carefully monitored the information about COVID-19; $157(44.6 \%)$ did so from time to time and only 27 (7.8\%) did not monitor the situation.

Most respondents ( $n=225,63.92 \%$ ) did not have any personal experience of the coronavirus infection. Of the 127 respondents who did have some experience, $63(17.9 \%)$ said that they or someone they knew had been infected by COVID-19; 37 (10.51\%) answered that they or someone they knew had been hospitalized due to COVID-19; only 12 (3.41\%) people knew someone who had died from COVID-19 and 15 (4.26\%) were medical professionals who worked with COVID-19 patients. 


\section{Primary endpoint}

Of the 352 participants, only 49 (13.92\%) had abnormal levels of anxiety (HADS-A score > 10); 56 (15.91\%) people had borderline abnormal levels of anxiety (HADS-A score of 8-10) (Figure 1). Abnormal levels of depression (HADS-D score $>10)$ were revealed in $30(8.52 \%)$ participants, and borderline levels (a score of 8-10) were indicated in 29 (8.24\%) people. Higher than normal levels of HADS anxiety/depression were observed in 105 (29.83\%) and 59 (16.76\%) respondents, respectively; mean $(95 \% \mathrm{Cl})$ scores for HADS anxiety/depression were 6.23 [5.77, $6.68] / 4.65[4.22,5.08]$ (women) and 4.20 [3.32, 5.09] 13.46 [2.63, 4.29] (men), respectively. Abnormal scores were recorded by 42 (11.93\%) participants for both the anxiety and depression scale. Normal levels of anxiety and depression were prevalent in our sample (HADS-A: $\chi^{2}=221.4, d f=2, p<0.0001 ;$ HADS-D: $\chi^{2}=395.5, d f=2$, $p<0.0001$ ) (Table 1).

\section{Secondary endpoints}

Abnormal levels of anxiety were significantly more frequent in women than in men $\left(\chi^{2}=8.21, \mathrm{df}=2\right.$, $p=0.017$; Table 1). Another variable besides gender, which had a significant influence on the level of anxiety, was present or past history of mental health problems (as reported by respondents) $\left(X^{2}=111.29, \mathrm{df}=10\right.$, $p<0.001)$. Moreover, of those who had had psychiatric problems in the past $(n=52), 11$ reported abnormal levels of anxiety and 15 were borderline abnormal, whereas of the 300 people who reported not having previously had psychiatric problems (including those who had problems at the time of the survey), only 38 and 41 reported abnormal or borderline abnormal anxiety, respectively $\left(X^{2}=12.25, d f=2, p=0.002\right)$.

Personal experience of COVID-19 of any kind (being infected or hospitalized, knowing someone who was infected, hospitalized or had died due to COVID-19) was found to be associated with increased HADS-A scores, although mean scores did not reach even borderline levels of anxiety (mean HADS-A scores of people who had experience of COVID-19: 6.724 [6.046; 7.403]; mean HADS-A scores of people with no experience of COVID-19: 5.280 [4.770; 5.790]; post-hoc test for contrast: $t=-3.347$, $p<0.001$ ). Other variables (level of education, living conditions, marital status, occupation, medical education, etc.) were not found to have any significant influence on the level of anxiety in respondents.
Unlike the HADS-A results, levels of HADS-D scores did not differ significantly between men and women. The only variables found to influence depression scores were living conditions and past or present mental health problems (as reported by respondents): people who lived in a shared apartment (rooms) had significantly higher HADS-D scores $\left(\chi^{2}=23.57, \mathrm{df}=6, p<0.001\right)$, and those who had experienced mental health problems had higher HADS-D scores $\left(\chi^{2}=56.6, d f=10, p<0.0001\right)$.

\section{Distress}

Most respondents ( $n=208,59.4 \%$ ) estimated their level of distress to be $<5$ on the 10-point scale (Figure 2).

All respondents were asked to identify causes of distress if they had any. The leading causes of distress were (in the order of incidence) as follows: 1) the risk of financial problems in the future $(n=267,76.3 \%) ; 2$ ) violation of plans and the collapse of normal life ( $n=235,67.1 \%$; and $n=240$, $68.6 \%$, respectively); 3 ) the health of elderly or chronically diseased relatives ( $n=205,58.6 \%)$ and 4$)$ being in selfisolation ( $n=186,53.1 \%$ ). Less than $30 \%$ of respondents reported having problems in terms of relationships with family members (children, a partner or elderly relatives). Being stigmatized due to COVID-19, having work overload or being at risk of losing a job were also among the less common reasons for distress (Figure 3).

Estimation of demographic variables associated with distress levels, attitude towards COVID-19 and sources of distress found to have an importance of 0.25 or higher in the regression model were as follows: the need for psychological support; changes in psychological condition; worries about the family's financial situation; worries about the current situation; mental health; present or future financial risks and other health problems. When these variables were entered into the regression tree model (Figure 4), the best fit model included the following: the need for psychological support; changes in psychological condition; worries about the family's financial situation and mental health.

Our research sample was split according to the need for psychological support reported by respondents. Those who did not feel the need for psychological support had a lower mean score for distress (group size, mean distress level and variance: $n=210, M=3.00, D=5.84$ ), while those who felt this need had a mean score of $6.57(n=49, M=$ $6.57, D=3.83$ ). Those who chose the "difficult to answer" option also had a higher level of distress $(n=93, M=4.78$, 


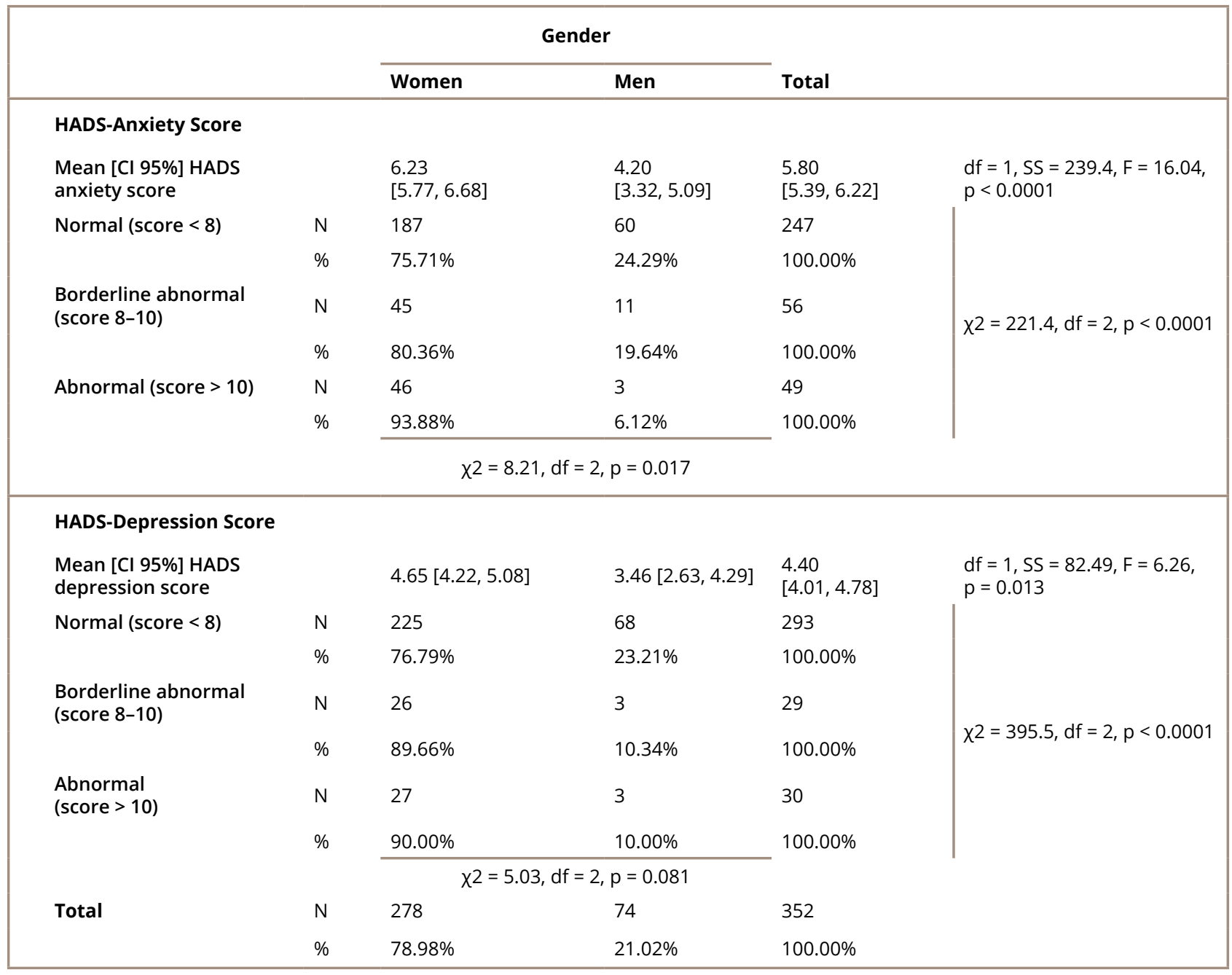

$D=4.66$ ). People in this group also had worries about family finances. Those who felt that they did not need psychological support could be split into two groups according to changes in their psychological condition ("yes" or "no" answers). Those who mentioned a change in psychological condition during the pandemic had higher levels of distress ( $n=67, M=4.16, D=6.52)$. Among these respondents, we also identified a group of people who had some concerns about family finances $(n=41, M=5.02$, $D=6.85$ ) but who were not overly worried about this issue $(\mathrm{n}=26, \mathrm{M}=2.8, \mathrm{D}=3.00)$.

\section{DISCUSSION}

The survey was performed during the fourth week of lockdown, which officially started from 30 March (about two weeks later than in most European countries).
This enabled us to obtain information about the realities of lockdown and people's experiences in neighbouring countries. Information about coronavirus started to appear in the mass media and on the internet in January and became the main media topic at the beginning of March. The total number of infected cases in Russia rose during the course of our survey, from 57,999 at the start (22 April) to 87,147 people by the end (27 April) [21].

In line with data from countries that had already experienced a coronavirus outbreak and lockdown, we expected to see a higher prevalence of anxiety and depression than usual among the general population in the midst of the epidemic in Russia. In our sample, we did not find a great prevalence of subclinical or clinical levels of depression or anxiety in the sample using the HADS 


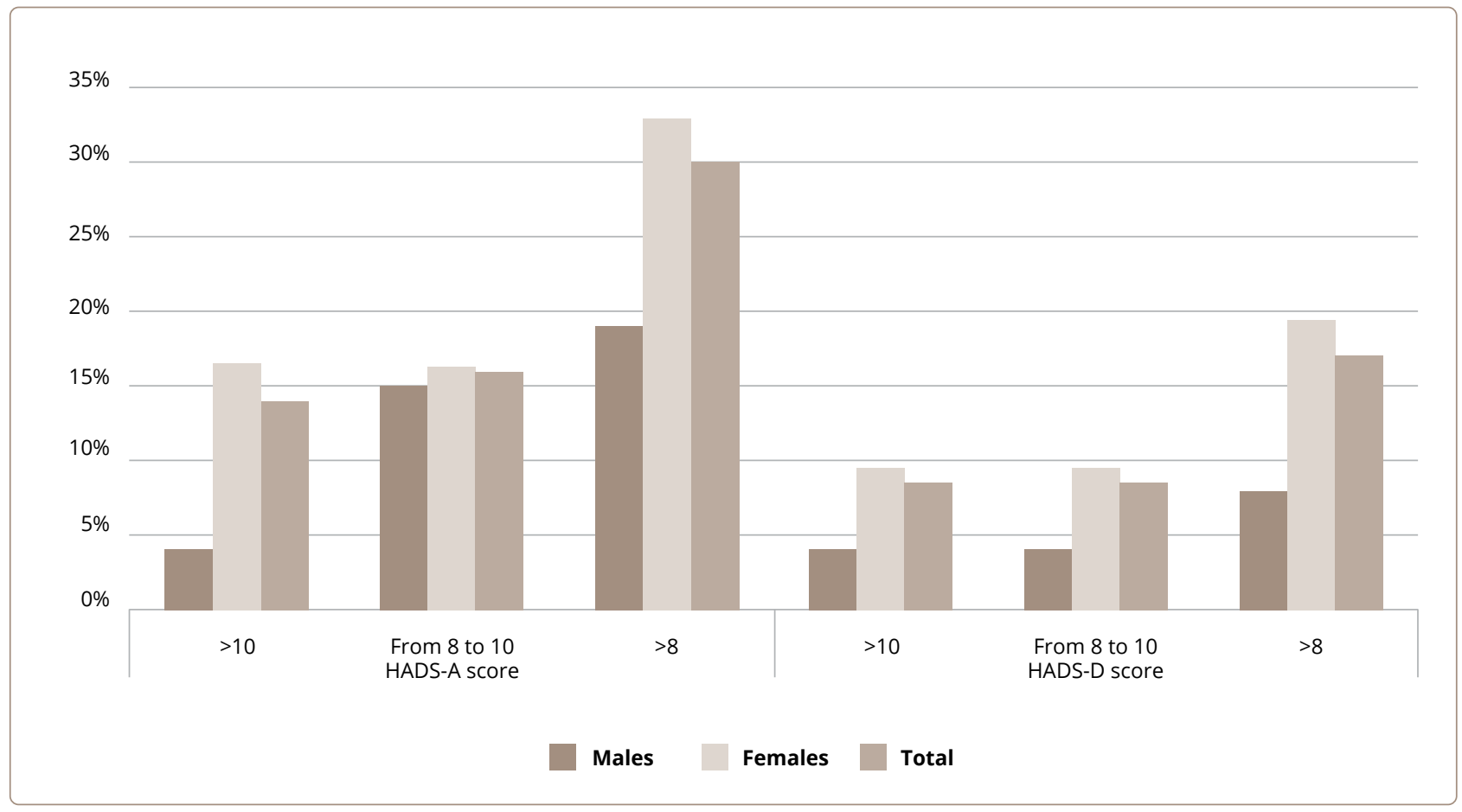

Figure 1. Relative frequencies of scores for abnormal $(>10)$, borderline abnormal $(>8)$ and normal $(<7)$ levels of anxiety (HADS-A) and depression (HADS-D)

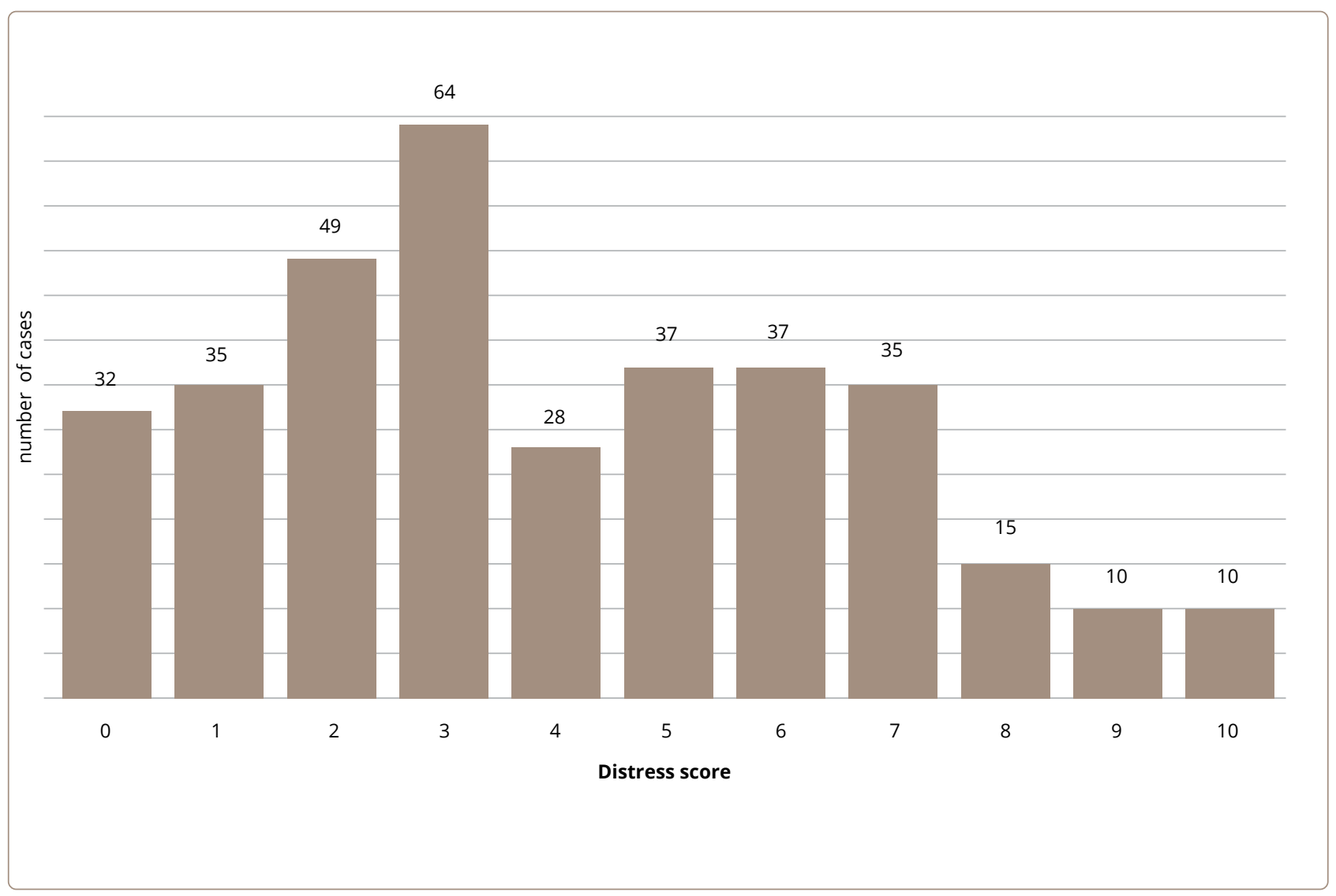

Figure 2. Levels of distress in the sample 


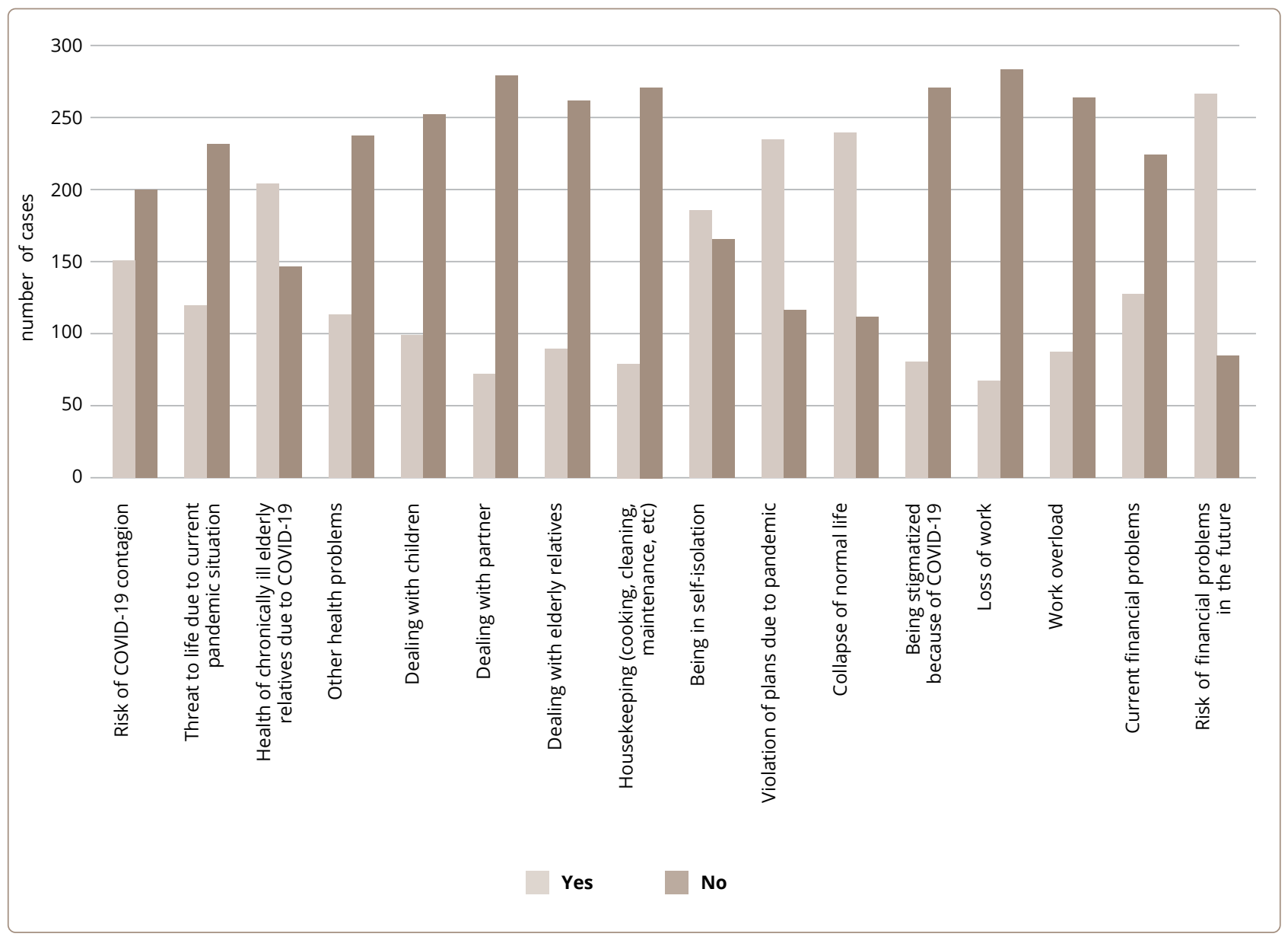

Figure 3. Causes of distress

scale. In our sample, abnormal levels ( $>10)$ of anxiety and depression were observed in $13.9 \%$ (4.1\% in men and $16.5 \%$ in women) and $8.5 \%$ (4.1\% in men and $9.7 \%$ in women) of respondents, respectively and we found higher than normal levels ( $>7)$ in $29.8 \%$ (18.9\% in men and $32.7 \%$ in women) and $17.0 \%$ (8.1\% in men and $19.4 \%$ in women) of respondents, respectively. This is lower than was estimated for both abnormal anxiety/depression (18.1\% in total, $10.9 \%$ in men and $22.7 \%$ in women for anxiety; $8.8 \%$ in total, $6.7 \%$ in men and $10.0 \%$ in women for depression), and it constitutes a higher than average level of anxiety/depression $(46.3 \%$ in total, $35.5 \%$ in men and $54.9 \%$ in women for anxiety; $25.6 \%$ in total, $20.6 \%$ in men and $28.6 \%$ in women for depression) in terms of the Russian general population ( $N=16,877$ ) [22]. It is also similar to estimates based on a sample of the German general population ( $\mathrm{N}=4410)$. In men and women, abnormal anxiety is $5.2 \%$ and $8.1 \%$, respectively; abnormal depression is $9.6 \%$ and $9.3 \%$, respectively; higher than normal anxiety is $18.1 \%$ and $23.2 \%$ respectively and higher than average depression is $23.9 \%$ and $23.5 \%$, respectively [23]. In our study, higher levels of anxiety and depression were found to be associated with a self-reported history of mental health problems and the female gender, while higher depression levels were more frequent among people with disadvantaged living conditions.

Although the mean scores for anxiety/depression in our study were lower $(6.23 / 4.65$ for women and 4.20/3.46 for men), they are within the limits of known population norms published by Shal'nova S.A. et al. for the Russian Federation (8.1/5.4 for women and 6.7/4.5 for men) [22], and they are closer to other known norms that were estimated in Germany ( $N=4410)$ : anxiety/depression 5.0/4.7 (females) and 4.4/4.8 (males) [23].

Our results differ from the results of similar surveys carried out during the pandemic, where excessive levels 


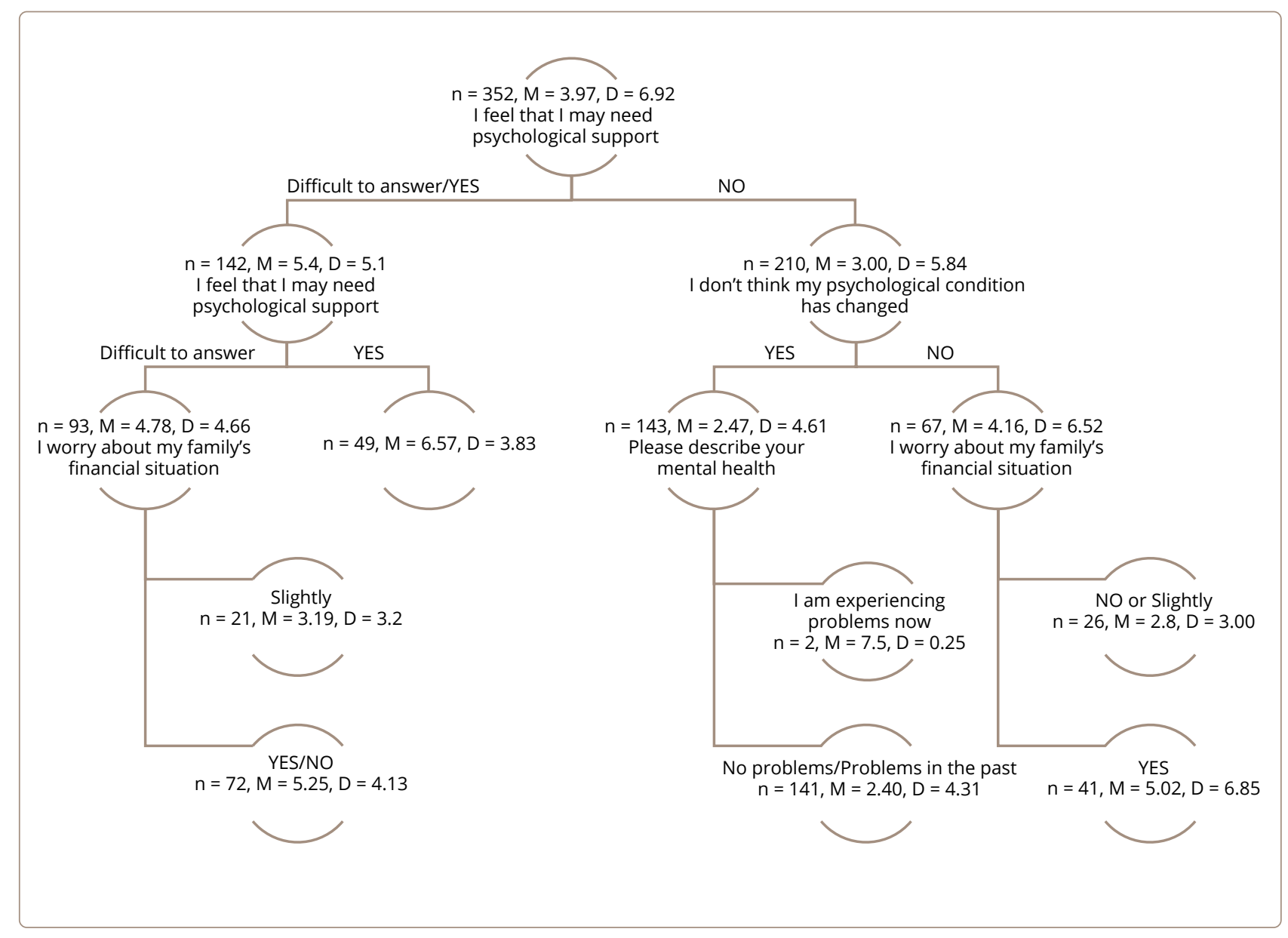

Figure 4. Regression tree model

of depression and anxiety were found either by using the HADS [24] or the Depression, Anxiety and Stress Scale (DASS-21) [6-8]. Moreover, our results cannot be explained by the careless attitude of people towards the pandemic among the examined sample (with most respondents sharing the view that the pandemic is a serious threat and most being ready to wait out the quarantine); nor can they be explained by a lack of information because $92.2 \%$ reported receiving it. Our findings relating to normal levels of HADS-A and HADS-D may partly be explained by the fact that only $14 \%$ of respondents had personal experience of severe consequences of the COVID-19 infection, such as hospitalization or the death of people close to them. Furthermore, the strict countermeasures aimed at curtailing the spread of COVID-19 were implemented in the context of a consistently low estimated mortality rate and possibly led to a waning of the initial psychological reaction. Another reason is the biased sample in terms of social and demographic characteristics, with a prevalence of women and high levels of education among respondents, along with an absence of people with lower levels of education, elderly people and migrants, i.e., people from the most vulnerable social groups, who have been proven to suffer emotional problems during the pandemic $[4,9,12,13]$.

In our study, an additional instrument was used for self-assessment of subjective distress levels and the causes of distress, along with questions about the need for psychological support and changes in psychological well-being. It is interesting to note that in our sample, people showed high levels of awareness regarding whether they had any psychological problems: higher levels of perceived distress were associated with the need for psychological support and awareness of changes in psychological well-being (Figure 4). It seems that subjective evaluation of distress levels in our survey was more informative in terms of detecting problems with mental well-being, compared with the HADS, which was 
originally designed for depression and anxiety screening in general medical settings.

The leading causes of distress were found to be associated with financial concerns and self-isolation, and the health of elderly or chronically ill relatives. The risk of being infected with COVID-19 or concerns about the threat to life were not the main reasons for distress, nor was the fear of being stigmatized due to COVID-19. Difficulties associated with dealing with family members (children, a partner or elderly relatives) had even less impact on distress. These results do not correspond with assumptions made by the WHO about possible causes of distress (reflected in its information sheets) [25] or with the results of another survey carried out during the first week of the COVID-19 pandemic in Russia [26].

The leading sources of distress captured in our study may differ from the sources of distress at various stages of lockdown. In the study mentioned above (carried out at the beginning of April), the top concerns (in descending order) were the risk to the lives and health of relatives (77.2\%), possible financial difficulties (57.0\%) and severe social consequences (49.5\%) [26], whereas in our study (conducted at the end of April), the leading cause was the risk of financial problems in the future (76.3\%), followed by violation of plans and the collapse of normal life $(67.1 \%)$, the health of elderly or chronically diseased relatives (58.6\%) and being in self-isolation (53.1\%).

\section{LIMITATIONS}

The main limitation of our survey is the unknown selection bias [27]. The link to the survey was disseminated via the social environment of the authors (via chat platforms, social internet networks and emails). People were encouraged to continue sharing the link with their contacts. Therefore, we do not know the sampling frame. The Google forms platform does not provide information on the number of survey entries, the number of partial responses or the number of people who do not respond at all. Therefore, the limitations of our study are comparable with other online mental health surveys carried out during the pandemic [28].

The respondents in the sample used for the analysis have specific demographic and social characteristics, with a prevalence of women and high levels of education. Furthermore, although the study sample was large enough for a statistical analysis, it was far smaller than the samples used in other studies, which comprised thousands of participants. Another limitation is the fact that most respondents were from Moscow. On the other hand, the fact that most of our respondents were from the capital city allows us to make comparisons with other international studies carried out in megacities all over the world known to be the epicentre of the epidemic in their respective countries.

\section{CONCLUSIONS}

The level of anxiety and depression reported during the COVID-19 pandemic in the study sample did not exceed the population norm that was assessed in the usual (non-pandemic) situation. The specific demographic and social characteristics of the sample (a prevalence of high levels of education among respondents, less personal experience of coronavirus and relatively high levels of social well-being) could explain the low levels of depression and anxiety found, and the low incidence of severe distress. Notwithstanding this, we did find the female gender and a history of mental health problems to be associated with higher levels of anxiety and depression.

It seems that self-reports of psychological well-being and subjective distress assessments are informative screening tools for detection of people who have distressing emotional reactions. Such screening tools may be more useful for the general population during periods of crisis, rather than as tools designed to measure clinical levels of emotional disturbance, such as anxiety or depression. In our survey, the HADS scale turned out to be less sensitive in capturing existing emotional problems, while use of the subjective distress scale revealed individuals in need of psychological support and a change in their psychological well-being.

Mental health professionals should focus on the causes of distress when developing psychological support interventions, and the relevant authorities should do likewise when media strategies are being developed to manage (reduce) the impact of "infodemic" [29] on the public and when social support programmes are being devised.

Acknowledgements: We would like to thank Dr. Natalia N. Zakharova for the initiation surveys on COVID-19 and mental health in Mental Health Clinic No. 
16 named after N.A. Alekseev, and for the creation of the first version of the questionnaire.

\section{Author Contributions: Olga A. Karpenko:} methodology, conceptualization, organization of the study, analysis of results, text preparation; Timur S. Syunyakov: methodology, statistical data processing, conceptualization, text preparation; Maya A. Kulygina: methodology, analysis of literature, conceptualization, text preparation, editing; Alexey V. Pavlichenko: methodology, editing; Anastasia S. Chetkina: analysis of literature; Alisa V. Andrushchenko: methodology, editing, conceptualization, supervision.

Funding: The research was carried out without additional funding.

Conflict of Interest: The authors report no conflicts of interest.

\section{Correspondence to:}

\section{Olga Karpenko}

drkarpenko@gmail.com

\section{References}

1. Brooks SK, Webster RK, Smith LE, Woodland L, Wessely S, Greenberg N, et al. The psychological impact of quarantine and how to reduce it: rapid review of the evidence. Lancet. 2020;395(10227):912-20. Epub 2020/03/01. doi: 10.1016/S01406736(20)30460-8. PubMed PMID: 32112714; PubMed Central PMCID: PMCPMC7158942.

2. Sritharan J, Sritharan A. Emerging mental health issues from the novel coronavirus (COVID-19) pandemic. Journal of Health and Medical Sciences. 2020;3(2):157-62. doi: 10.31014/ aior.1994.03.02.109.

3. Zeppegno P, Gramaglia C, Guerriero C, Madeddu F, Calati R. Psychological/psychiatric impact of the novel coronavirus outbreak: lessons learnt from China and call for timely crisis interventions in Italy [Internet]. PsyArXiv. 2020 [cited 2020 Aug 15]. Available from: psyarxiv.com/z26yk.

4. Lima CKT, Carvalho PMM, Lima I, Nunes J, Saraiva JS, de Souza $\mathrm{Rl}$, et al. The emotional impact of Coronavirus 2019-nCoV (new Coronavirus disease). Psychiatry research. 2020;287:112915. Epub 2020/03/22. doi: 10.1016/j.psychres.2020.112915. PubMed PMID: 32199182; PubMed Central PMCID: PMCPMC7195292.

5. Qiu J, Shen B, Zhao M, Wang Z, Xie B, Xu Y. A nationwide survey of psychological distress among Chinese people in the COVID-19 epidemic: implications and policy recommendations. Gen Psychiatr. 2020;33(2):e100213. Epub 2020/03/28. doi: 10.1136/ gpsych-2020-100213. PubMed PMID: 32215365; PubMed Central PMCID: PMCPMC7061893.

6. Wang C, Pan R, Wan X, Tan Y, Xu L, Ho CS, et al. Immediate Psychological Responses and Associated Factors during the Initial Stage of the 2019 Coronavirus Disease (COVID-19)
Epidemic among the General Population in China. Int J Environ Res Public Health. 2020;17(5). Epub 2020/03/12. doi: 10.3390/ ijerph17051729. PubMed PMID: 32155789; PubMed Central PMCID: PMCPMC7084952.

7. Wang C, Pan R, Wan X, Tan Y, Xu L, McIntyre RS, et al. A longitudinal study on the mental health of general population during the COVID-19 epidemic in China. Brain, behavior, and immunity. 2020;87:40-8. Epub 2020/04/17. doi: 10.1016/j. bbi.2020.04.028. PubMed PMID: 32298802; PubMed Central PMCID: PMCPMC7153528.

8. Kwok KO, Li KK, Chan HHH, Yi YY, Tang A, Wei WI, et al. Community Responses during Early Phase of COVID-19 Epidemic, Hong Kong. Emerg Infect Dis. 2020;26(7):1575-9. Epub 2020/04/17. doi: 10.3201/eid2607.200500. PubMed PMID: 32298227; PubMed Central PMCID: PMCPMC7323558.

9. Alyami HS, Naser AY, Dahmash EZ, Alyami MH, Al Meanazel OT, Al-Meanazel AT, et al. Depression and anxiety during 2019 coronavirus disease pandemic in Saudi Arabia: a cross-sectional study. medRxiv. 2020:2020.05.09.20096677. doi: 10.1101/2020.05.09.20096677.

10. Gerhold L. COVID-19: Risk perception and coping strategies. Results from a survey in Germany [Internet]. PsyArXiv, 25 Mar 2020 [cited 2020 Aug 15] Available at: https://psyarxiv.com/ xmpk4. Preprint DOI: 10.31234/osf.io/xmpk4.

11. World Health Organization (WHO) [Internet]. Substantial investment needed to avert mental health crisis. [Internet] [cited 2020 Aug 15]. Available from: https://www.who.int/ru/news-room/ detail/14-05-2020-substantial-investment-needed-to-avertmental-health-crisis.

12. Kong $\mathrm{X}$, Zheng $\mathrm{K}$, Tang $\mathrm{M}$, Kong F, Zhou J, Diao L, et al. Prevalence and Factors Associated with Depression and Anxiety of Hospitalized Patients with COVID-19. medRxiv. 2020:2020.03.24.20043075. doi: 10.1101/2020.03.24.20043075.

13. Yuan R, Xu Q-h, Xia C-c, Lou C-y, Xie Z, Ge Q-m, et al. Psychological status of parents of hospitalized children during the COVID-19 epidemic in China. Psychiatry research. 2020;288:112953. doi: https://doi.org/10.1016/j.psychres.2020.112953.

14. Kang L, Li Y, Hu S, Chen M, Yang C, Yang BX, et al. The mental health of medical workers in Wuhan, China dealing with the 2019 novel coronavirus. Lancet Psychiatry. 2020;7(3):e14. Epub 2020/02/09. doi: 10.1016/S2215-0366(20)30047-X. PubMed PMID: 32035030; PubMed Central PMCID: PMCPMC7129673.

15. Lai J, Ma S, Wang Y, Cai Z, Hu J, Wei N, et al. Factors associated with mental health outcomes among health care workers exposed to coronavirus disease 2019. JAMA Netw Open. 2020;3(3):e203976. Epub 2020/03/24. doi: 10.1001/ jamanetworkopen.2020.3976. PubMed PMID: 32202646; PubMed Central PMCID: PMCPMC7090843.

16. Cao W, Fang Z, Hou G, Han M, Xu X, Dong J, et al. The psychological impact of the COVID-19 epidemic on college students in China. Psychiatry research. 2020;287:112934. Epub 2020/04/02. doi: 10.1016/j.psychres.2020.112934. PubMed PMID: 32229390; PubMed Central PMCID: PMCPMC7102633.

17. Wind TR, Rijkeboer M, Andersson G, Riper H. The COVID-19 pandemic: The 'black swan' for mental health care and a turning point for e-health. Internet Interv. 2020;20:100317. Epub 2020/04/15. doi: 10.1016/j.invent.2020.100317. PubMed PMID: 32289019; PubMed Central PMCID: PMCPMC7104190.

18. Ru.wikipedia.org [Internet]. [Prevalence of COVID-19 in Moscow] [cited 2020 Aug 15]. Available from: https://ru.wikipedia.org/wiki/ Распространение_COVID-19_в_Москве. Russian. 
19. Zigmond AS, Snaith RP. The hospital anxiety and depression scale. Acta psychiatrica Scandinavica. 1983;67(6):361-70. Epub 1983/06/01. doi: 10.1111/j.1600-0447.1983.tb09716.x. PubMed PMID: 6880820 .

20. World Health Organization (WHO) [Internet]. WHO briefing note - Mental health and psychosocial considerations during COVID-19 outbreak [cited 2020 Aug 15]. Available from: https:// www.who.int/docs/default-source/coronaviruse/mental-healthconsiderations.pdf?sfvrsn=6d3578af_10.

21. World Health Organization (WHO) [Internet]. Coronavirus disease (COVID-2019) situation reports [cited 2020 Aug 15]. Available from: https://www.who.int/emergencies/diseases/novelcoronavirus-2019/situation-reports.

22. Shal'nova SA, Evstifeeva SE, Deev AD, Artamova GV, Gatagonova TM, Dupliakov DV, et al. [The prevalence of anxiety and depression in different regions of the Russian Federation and its association with sociodemographic factors (according to the data of the ESSE-RF study)]. Terapevticheskii arkhiv. 2014;86(12):53-60. Epub 2014/01/01. doi: 10.17116/terarkh2014861253-60. PubMed PMID: 25804041. Russian.

23. Hinz A, Brähler E. Normative values for the hospital anxiety and depression scale (HADS) in the general German population. Journal of psychosomatic research. 2011;71(2):74-8. Epub 2011/07/20. doi: 10.1016/j.jpsychores.2011.01.005. PubMed PMID: 21767686.
24. White RG, Van Der Boor C. The impact of the COVID19 pandemic and initial period of lockdown on the mental health and wellbeing of UK adults. medRxiv. 2020:2020.04.24.20078550. doi: 10.1101/2020.04.24.20078550.

25. World Health Organization (WHO) [Internet]. Mental health and COVID-19 [cited 2020 Aug 15]. Available from: http://www.euro. who.int/en/health-topics/noncommunicable-diseases/mentalhealth/data-and-resources/mental-health-and-covid-19.

26. Sorokin MY, Kasyanov ED, Rukavishnikov GV, Makarevich OV, Neznanov NG, Lutova NB, et al. Structure of anxiety associated with the COVID-19 pandemic in the Russian-speaking sample: results from on-line survey. Bulletin of RSMU. 2020;(3):70-6. doi: 10.24075/brsmu.2020.030.

27. Bethlehem J. Selection Bias in Web Surveys. International Statistical Review. 2010;78(2):161-88. doi: 10.1111/j.17515823.2010.00112.x

28. Pierce M, McManus S, Jessop C, John A, Hotopf M, Ford T, et al. Says who? The significance of sampling in mental health surveys during COVID-19. Lancet Psychiatry. 2020;7(7):567-8. Epub 2020/06/06. doi: 10.1016/s2215-0366(20)30237-6. PubMed PMID: 32502467; PubMed Central PMCID: PMCPMC7266586.

29. The Lancet. COVID-19: fighting panic with information. Lancet. 2020;395(10224):537. Epub 2020/02/24. doi: 10.1016/s01406736(20)30379-2. PubMed PMID: 32087777; PubMed Central PMCID: PMCPMC7138040. 